\title{
Growth and Yield Responses of Cowpea and Groundnut to Five Rhizobial Inoculant Strains in the Guinea Savanna Zone of Ghana
}

\author{
F. Mintah, ${ }^{1}$ Y. Z. Mohammed, ${ }^{1}$ S. Lamptey ${ }^{10},{ }^{1}$ and B. D. K. Ahiabor ${ }^{2}$ \\ ${ }^{1}$ Department of Agronomy, University for Development Studies, Tamale, Ghana \\ ${ }^{2}$ CSIR-Savanna Agricultural Research Institute, Tamale, Ghana \\ Correspondence should be addressed to S. Lamptey; naalamp2009@yahoo.com
}

Received 9 September 2020; Revised 4 November 2020; Accepted 8 November 2020; Published 3 December 2020

Academic Editor: Gábor Kocsy

Copyright (c) 2020 F. Mintah et al. This is an open access article distributed under the Creative Commons Attribution License, which permits unrestricted use, distribution, and reproduction in any medium, provided the original work is properly cited.

Inoculating groundnut and cowpea with highly effective and competitive rhizobial strain improves nodulation. A field experiment was carried out at the experimental field of the Faculty of Agriculture, University for Development Studies, Nyankpala, to evaluate the growth and yield responses of cowpea and groundnut to five rhizobial inoculant strains in the Guinea Savanna zone. The experiment was laid out in a randomized complete block design (RCBD) with eight (8) treatments replicated four (4) times. The treatments included five rhizobial inoculant strains (NC 92, KNUST 1002, KNUST 1003, KNUST 1006, and BR 3267), two N fertilizer levels $(20 \mathrm{~kg} \cdot \mathrm{N} / \mathrm{ha}$ and $40 \mathrm{~kg} \cdot \mathrm{N} / \mathrm{ha})$, and a control. The results showed that rhizobial inoculation and N fertilizer application increased nodulation, biomass yield, pod number, pod weight, hundred seed weight, nodule dry weight, and pod yield of groundnut compared with the control. Rhizobial inoculation averagely increased the nodulation and yield by 63 and $67 \%$, respectively, compared with the control. Mineral N fertilizer $(20 \mathrm{~kg} \mathrm{~N} / \mathrm{ha})$ on average increased the nodulation and yield by 24 and $25 \%$, respectively, compared with the control plots. It can be recommended from this study that, in the absence of highly competitive rhizobial strains such as KNUST 1006 and NC 92 as biofertilizers for increasing the nodulation and yield of cowpea and groundnut, $20 \mathrm{~kg} \cdot \mathrm{N} / \mathrm{ha}$ can be used for the purpose. Further research is recommended using these rhizobial strains in combination with lower rates of $\mathrm{N}$ fertilizers $\left(<20 \mathrm{~kg} \cdot \mathrm{ha}{ }^{-1}\right)$.

\section{Introduction}

Groundnut (Arachis hypogaea L.) and cowpea (Vigna unguiculata (L.) Walp) are among the most important leguminous crops cultivated worldwide, especially in tropical and subtropical regions as food crops [1] due to their drought resistance [2]. Groundnut and cowpea are grain legume crops cultivated in the Guinea Savanna zone of Ghana and are ranked as the number one grain legumes [3]. Management of nitrogen ( $\mathrm{N})$ fertilizer is one of the main problems since insufficient application rates may limit their productivity, and excessive $\mathrm{N}$ rates are not only costly but can also promote negative environmental impacts [4]. According to FAO [5], there are limited uses of fertilizers among farmers in Ghana, which is estimated to be less than $8 \mathrm{~kg} / \mathrm{ha}$. This may be due to high costs of fertilizers and its limited availability in farming communities, which may be as a result of inadequate subsidies provided by the government [6]. This eventually makes it difficult for farmers to get the required amount of fertilizer necessary to increase crop yield. Biological nitrogen fixation is a less expensive alternative for overcoming these challenges and results in soil nitrogen replenishment and crop productivity improvement [7]. Groundnut and cowpea can obtain much of their $\mathrm{N}$ requirements through symbiotic nitrogen fixation if the root nodules are infected by effective strains of rhizobia [8]. Rhizobial inoculation has the capability of increasing the growth and yield components of nodulating legumes, and this will eventually increase the number of nodules and the amount of nitrogen fixed into the soil [9]. Reference [10] reported that groundnut and cowpea plants with symbiotic nitrogen fixing bacteria are able to fix about 15 to $210 \mathrm{~kg} / \mathrm{ha}$ of nitrogen per season in Africa. The use of rhizobia as biofertilizer (inoculants) has been reported to increase 
nodulation and pod yield of groundnut [1]. One major problem in acquiring quality inoculants for inoculation is the low number of effective rhizobia in terms of nodulation and nitrogen fixation of the host plant [11]. Studies have shown that the bacteria produced by the inoculant help the plant in producing nodules on the roots that are responsible for fixing nitrogen $[12,13]$. The full potential of the symbiotic system may not be realized because of inefficient strains of rhizobia [14]. Using inefficient rhizobial strains to inoculate is not competitive and effective and therefore could not potentially increase grain legume production [15]. Also, effectiveness of the indigenous strain can influence inoculation response $[16,17]$. There is therefore the need to identify and select an effective rhizobial strain that can effectively outcompete the indigenous population for nodule site to improve nodulation and nitrogen fixation [11] in cowpea and groundnut for improved yield in the Guinea Savanna. This will minimize the use of chemical $\mathrm{N}$ fertilizers, which are rather costly and deteriorate soil properties [7].

\section{Materials and Methods}

2.1. Experimental Site. The study was conducted at the experimental field of the Faculty of Agriculture, University for Development Studies (U. D. S), Nyankpala, in the Tolon District of the Northern Region of Ghana during the 2018 cropping season. The vegetation is savanna grassland which is characterized by shrubs and few scattered trees. The climate of the area is tropical, warm, and semiarid with an average annual unimodal rainfall of $1100 \mathrm{~mm}$. The mean day temperature ranges from $33^{\circ} \mathrm{C}$ to $39^{\circ} \mathrm{C}$, while mean night temperatures range from $20^{\circ} \mathrm{C}$ to $22^{\circ} \mathrm{C}$. The mean relative humidity varies from 78 to $83 \%$ from June to September and gradually decreases to about $15-26 \%$ during the dry season [18]. The texture of the soil is mainly silt or sandy loam. It is generally of shallow depth, and below the surface is a concentrated layer of iron pan, through which rain water does not penetrate easily. It therefore becomes waterlogged in rainy season but dries out completely during the dry season. Soil fertility is the major constraint in the study area which is in line with [19].

Historically, the field had not been used for the cultivation of any leguminous crop but has been used for the cultivation of maize for the past three years preceding the current study.

2.2. Experimental Design. The experiment was laid out in a randomized complete block design (RCBD) with eight (8) treatments which were replicated four (4) times. The treatments included five rhizobial inoculant strains (NC 92, KNUST 1002, KNUST 1003, BR 3267, and KNUST 1006), two $\mathrm{N}$ fertilizer levels ( $20 \mathrm{~kg} \mathrm{~N} / \mathrm{ha}$ and $40 \mathrm{~kg} \mathrm{~N} / \mathrm{ha}$ ), and absolute control (without $\mathrm{N}$ or inoculation) giving a total of 32 experimental units. The plot size for each experimental unit for both cowpea and groundnut was $4.2 \mathrm{~m} \times 3.0 \mathrm{~m}$ $\left(12.6 \mathrm{~m}^{2}\right)$, and the spacings between plots and replications (blocks) were $1 \mathrm{~m}$ and $2 \mathrm{~m}$, respectively. Sowing was done on $27^{\text {th }}$ June, 2018, for the groundnut and $17^{\text {th }}$ August, 2018, for cowpea. The cowpea and the groundnut experiment were about $15 \mathrm{~m}$ apart. Both cowpea and groundnut were planted at a distance of $60 \mathrm{~cm} \times 20 \mathrm{~cm}$ and at a depth of $5 \mathrm{~cm}$. The cowpea and groundnut varieties used were Wang-Kae and Nkatie-SARI, respectively. The noninoculated seeds were sown first before sowing the inoculated ones to avoid any possibility of cross-contamination.

2.3. Weed Control and Fertilizer Application. The groundnut field was first weeded on $10^{\text {th }}$ July, 2018, exactly two (2) weeks after sowing (2 WAS), whilst it was weeded for a second and third timed 6 and 8 WAS, respectively. However, the cowpea trial was weeded only once on $30^{\text {th }}$ August, 2018, since Butachlor ( $50 \% \mathrm{EC}$ ), which is a selective preemergence herbicide, was applied labeled sacks and transport after sowing at the rate of $1 \mathrm{~L} / \mathrm{ha}$, which greatly suppressed weed growth. The manual weeding of both crops was done manually with a hoe.

The $20 \mathrm{~kg} \mathrm{~N} / \mathrm{ha}$ (54.8 g urea/plot) and $40 \mathrm{~kg} \mathrm{~N} / \mathrm{ha}(109.6 \mathrm{~g}$ urea/plot) treatments were applied as urea. The $20 \mathrm{~N}$ and $40 \mathrm{~N}$ fertilizer application was done 3 WAS: on $18^{\text {th }}$ July, 2018, for the groundnut field and on $28^{\text {th }}$ August, 2018 (3WAS), for the cowpea. The fertilizer was applied using the dibbling method; this is known to contribute to better crop growth compared to top dressing. Phosphate as triple super phosphate (TSP) and $\mathrm{K}$ as muriate of potash (MoP) were all applied as basal fertilizers to all the treatments at the rates of $30 \mathrm{~kg} \cdot \mathrm{P} / \mathrm{ha}(164 \mathrm{~g} \cdot \mathrm{TSP} / \mathrm{plot})$ and $30 \mathrm{~kg} \cdot \mathrm{K} / \mathrm{ha} \quad(126 \mathrm{~g} \cdot \mathrm{MoP} /$ plot), respectively [20].

2.4. Biomass Sampling and Nodulation of Cowpea and Groundnut. The first and second samplings of biomass and nodules were done at 36 and 56 days after sowing for cowpea and 51 and 68 days after sowing for groundnut. Ten plants were carefully scooped out from the soil with the help of a shovel, and any fallen nodules were collected in small plastic bags and kept together with the biomass well-labeled sacks and transported to the soil microbiology laboratory at CSIRSARI for further treatment. At the lab, the roots with the nodules intact were severed from the shoots and then carefully and gently washed on a mesh to trap any detached nodules. The shoots were also washed in water in order to get rid of any adhering soil particles and other debris from the field. The root systems with the nodules were air-dried under the ceiling fan for about 30 to 40 minutes, after which the nodules were detached from the roots and counted and their fresh weights were taken and recorded. The nodules were oven-dried at $70^{\circ} \mathrm{C}$ for 48 hours and their dry weights were determined. The pods on the shoots were also detached, counted and their numbers recorded and their fresh weights determined for each treatment using a digital scale and recorded. After which the shoots were loaded into envelopes and oven-dried at $70^{\circ} \mathrm{C}$ for 48 hours. Their dry weights were then measured using a digital scale.

2.5. Sampling of Cowpea and Groundnut Pods. Harvesting of the groundnut pods was done at 121 DAS using a hoe to scoop the plant out of the soil. For the cowpea, the pods were 
first picked at 61 DAS when more than half of the pods in the yield plots $\left(6.3 \mathrm{~m}^{2}\right)$ were dried whilst the second and final picking was done at $71 \mathrm{DAS}$ when all the pods were dried. The pods of both the groundnut and the cowpea were further dried sufficiently in the sun on a concrete floor to obtain their dry weights.

After getting the pods from the four inner rows $\left(6.3 \mathrm{~m}^{2}\right)$ of the two crops, the plants from the same four inner rows were sampled, counted, tied together with a string, and weighed as field haulm weight per yield plot using a hanging scale. Two plants (haulms) were then randomly picked from the weighed lot from each plot and put into a well-labeled envelope and weighed to haulm field wt./subsample before. They were oven-dried at $70^{\circ} \mathrm{C}$ for 48 hours. The oven-dry weight of the subsample was used to compute the oven-dry weight of the total haulm harvested from the yield plot.

2.6. Hundred Seed Weight. After sun-drying the harvested pods, eighty good pods were randomly selected from plants from each experimental plot. The pods were shelled and the seeds counted and the values recorded as number of seeds/80 pods. From each set of seeds, 100 seeds were randomly selected and weighed. The values (in grams) were recorded as 100-seed weights which is an indicator of seed size.

2.7. Total Pod Yield. For groundnut, the sun-dry weight obtained after drying the harvested pods at maturity was taken as the pod yield. Total pod yield was determined from a net plot of $3 \mathrm{~m} \times 2.1 \mathrm{~m}\left(6.3 \mathrm{~m}^{2}\right)$ measured within four middle rows of each plot $\left(12.6 \mathrm{~m}^{2}\right)$. Plants within the net plot (the central rows) were harvested and sun-dried to lower moisture content and weighed using electronic scale. Yield for each treatment in $\mathrm{kg} / \mathrm{ha}$ was extrapolated.

2.8. Data Analysis. Data were analyzed using GENSTAT $12^{\text {th }}$ edition statistical software tool. Means were separated using the least significant difference (LSD) method at 5\% probability level $(P<0.05)$.

\section{Results}

3.1. Rhizobial Inoculation Effect on Cowpea and Groundnut Shoot Dry Weight. Among the rhizobial strains, KNUST 1002 and NC 92 recorded the highest shoot biomass in groundnut and cowpea, respectively. However, both levels of mineral $\mathrm{N}$ fertilizer application increased biomass yield in groundnut whereas, in cowpea, only $20 \mathrm{~N}$ produced this positive effect (Table 1).

There were no significant differences among rhizobial inoculation and $\mathrm{N}$ treatments in nodule number compared to the control. However, nodule dry weight showed significant difference in both cowpea and groundnut (Table 2). The KNUST 1002 and BR 3267 strain recorded the greatest nodule dry weight in cowpea and groundnut, respectively. The control and $20 \mathrm{~N}$ recorded the least nodule dry weight in
TABLE 1: Effects of rhizobial inoculation and $\mathrm{N}$ fertilizer application on shoot dry weights of cowpea and groundnut grown at Nyankpala in the Guinea Savanna zone of Ghana. Nodule number and nodule dry weight.

\begin{tabular}{lcc}
\hline Treatment & \multicolumn{2}{c}{ Dry shoot weight/plant $(\mathrm{g})$} \\
Cowpea & Groundnut \\
\hline KNUST 1002 & 34.12 & 158.77 \\
KNUST 1006 & 34.52 & 144.82 \\
KNUST 1003 & 32.02 & 96.45 \\
BR 3267 & 36.92 & 100.70 \\
NC 92 & 39.27 & 93.60 \\
20 N & 50.02 & 159.10 \\
40 N & 39.20 & 179.69 \\
Control & 42.42 & 108.42 \\
LSD (0.05) & 3.7 & 20.6 \\
CV (\%) & 6.7 & 5.7 \\
\hline
\end{tabular}

TABLE 2: Influence of rhizobial inoculation and $\mathrm{N}$ fertilizer application on nodule number per plant and nodule dry weight/plant of cowpea and groundnut grown at Nyankpala in the Guinea Savanna zone of Ghana. Response of rhizobial inoculation on cowpea and groundnut pod yield.

\begin{tabular}{lcccc}
\hline \multirow{2}{*}{ Treatment } & \multicolumn{2}{c}{ Nodule number/plant } & \multicolumn{2}{c}{$\begin{array}{c}\text { Nodule dry weight/ } \\
\text { plant (mg) }\end{array}$} \\
& Cowpea & Groundnut & Cowpea & Groundnut \\
\hline KNUST 1002 & 10.26 & 43.40 & 0.56 & 0.40 \\
KNUST 1006 & 9.36 & 42.93 & 0.52 & 0.32 \\
KNUST 1003 & 10.64 & 32.63 & 0.53 & 0.35 \\
BR 3267 & 9.36 & 38.39 & 0.48 & 0.42 \\
NC 92 & 9.53 & 33.46 & 0.50 & 0.35 \\
20 N & 10.31 & 37.53 & 0.58 & 0.29 \\
40 N & 10.80 & 38.36 & 0.56 & 0.33 \\
Control & 10.60 & 35.30 & 0.28 & 0.31 \\
LSD (0.05) & 1.637 & 14.795 & 0.091 & 0.078 \\
CV (\%) & $11.1 \%$ & $26.1 \%$ & $12.4 \%$ & $13.8 \%$ \\
\hline
\end{tabular}

cowpea and groundnut, respectively. Rhizobial inoculation and $\mathrm{N}$ fertilizer application averagely increased nodule dry weight of groundnut by $71 \%$ and $23 \%$, respectively compared with the control.

Rhizobial inoculation significantly influenced pod number and weight of cowpea and groundnut (Table 3) with BR 3267 recording the greatest pod number among the rhizobial strains in both crops. Generally, inoculation with BR 3267 and application of $40 \mathrm{~kg} \cdot \mathrm{N} / \mathrm{ha}$ significantly improved number of pods compared to the other treatments in cowpea.

On average, rhizobial treatment (KNUST 1002 and $\mathrm{Br}$ $3267)$ and $\mathrm{N}$ fertilizer application ( $20 \mathrm{~N}$ and $40 \mathrm{~N})$ increased pod number by $27 \%$ and $28 \%$ for cowpea and $37 \%$ and $23 \%$ for groundnut, respectively, compared with the control. Treatment NC 92 and KNUST 1006 recorded the greatest pod weight in groundnut and cowpea as shown in Figures 1 and 2, respectively. KNUST 1006 recorded the greatest hundred seed weight in groundnut whereas KNUST 1002 and $\mathrm{NC} 92$ recorded the greatest in cowpea compared the control (Figures 3 and 4). 
TABLE 3: Effects of rhizobial inoculation and $\mathrm{N}$ fertilizer application on pod numbers of cowpea and groundnut grown at Nyankpala in the Guinea Savanna zone of Ghana.

\begin{tabular}{lcc}
\hline Treatment & Cowpea & Groundnut \\
\hline KNUST 1002 & 6 & 11 \\
KNUST 1006 & 6 & 6 \\
KNUST 1003 & 4 & 12 \\
BR 3267 & 7 & 21 \\
NC 92 & 5 & 12 \\
20 N & 6 & 9 \\
40 N & 7 & 11 \\
Control & 6 & 6 \\
LSD (0.05) & 0.4213 & 4.322 \\
CV $(\%)$ & 4.8 & 2.35 \\
\hline
\end{tabular}

3.2. Grain Yield. Total grain yield of cowpea and groundnut exhibited significant difference among treatments (Table 4). Among the rhizobia strains, treatment NC 92 and KNUST 1002 recorded the highest grain yield in groundnut and cowpea, respectively. The $20 \mathrm{~N}$ and $40 \mathrm{~N}$ nitrogen levels applied recorded slightly closed figures with a grain yield difference of 0.02 tons/ha in the cowpea field and difference of 0.04 in the groundnut field. Control treatment recorded the least grain yield in both cowpea and groundnut. Averagely, rhizobia and $\mathrm{N}$ fertilizer application increased groundnut grain yield by $68 \%$ and $26 \%$ and increased cowpea grain yield by $63 \%$ and $27 \%$, respectively, compared with the control.

\section{Discussion}

4.1. Rhizobial Inoculant Strains Improved Biomass in Cowpea and Groundnut. The greater biomass/dry shoot recorded by $20 \mathrm{~N}$ and $40 \mathrm{~N}$ in cowpea and groundnut, respectively, compared with other treatments in this study shows that mineral fertilizers do increase soil fertility, which in turn increases plant growth and development. This result is in conformity with [16], who observed that nitrogen-fertilized plots produced significantly greater biomass. Reference [21] also reported that the application of inorganic fertilizer leads to the production of more leaves and branches of both cowpea and groundnut. Nitrogen is responsible for dry matter accumulation [22], and according to [21], cowpea and groundnut plants that received inorganic nitrogen performed better than those that depended on biological nitrogen fixation. In the current study, the increased shoot dry weight observed in some of the strains compared to the control on groundnut may be that these strains effectively nodulated groundnut. This is in agreement with a research conducted by [23] that stated that inoculating legumes with effective rhizobial strains fixed adequate amount of nitrogen for host plant to use for production of plant biomass.

4.2. Nodule Number and Dry Weight. Results of dry weight of nodules from inoculations of cowpea and groundnut with rhizobial strains seem to suggest that some strains (KNUST 1002 and BR 3267, resp.) were more efficient than the native strains. This is in conformity with [11] who reported that inoculating groundnut and cowpea with highly competitive and efficient rhizobial strains increases nodulation of cowpea and groundnut. The outstanding performance of KNUST 1002 and BR 3267 in cowpea and groundnut in improving nodulation could imply that these strains were more compatible with the legumes host than the other strains. It could also be as a result of effective colonization of the host plant by the rhizobial strains, and this could lead to adequate $\mathrm{N}$ fixed into the soil for the plant to utilize for growth and development. The improved nodule dry weight in the application of $20 \mathrm{~N}$ and $40 \mathrm{~N}$ is in line with [24], who reported that application of $40 \mathrm{~kg} \cdot \mathrm{N} / \mathrm{ha}$ and $20 \mathrm{~kg} \cdot \mathrm{N} / \mathrm{ha}$ as $\mathrm{N}$ for groundnut production significantly increased nodule dry weight and grain yield of groundnut.

4.3. Pod Number and Pod Dry Weight. The improved number of pods and pod dry weight by some of the strains (e.g., improved pod dry weights of cowpea and groundnut by KNUST 1006 and NC 92, resp., as well as improved pod number by BR 3267 in both cowpea and groundnut) indicate that those strains were effective and perhaps were able to fix high amounts of nitrogen for the plant to utilize in the production of pods over the control treatment. This assertion is supported by [25], who reported that an increase in both pod number and pod dry weight of legumes following inoculation with rhizobial strains was a result of highly efficient nitrogen fixation by the inoculated strains compared with the native strains. Similar findings were also reported by [2]. The results obtained with BR 3267 relative to pod production in groundnut in this work are in agreement with the findings of Howarth et al. [26], who reported a positive response of pod number and pod dry weight of groundnut following inoculation and attributed this to the presence of effective strains of rhizobia inoculated. The higher number of pod obtained by the application of $40 \mathrm{~kg} \cdot \mathrm{N} / \mathrm{ha}$ compared with $20 \mathrm{~kg} \cdot \mathrm{N} / \mathrm{ha}$ in cowpea agrees with the studies carried out by [27], who reported significant increases in pod number by increasing the amount of nitrogen applied.

4.4. Hundred Seed Weight. The ability of rhizobial strains and minerals and $\mathrm{N}$ fertilizer application to increase groundnut hundred seed weight significantly over the control could also be as a result of nitrogen fixation that met the demand of the crop which influenced the growth of groundnut resulting in an increased hundred seed weight. This result is in line with Abdel-Wahab et al. [28], who showed that improvement in hundred-seed weight of groundnut may be attributed to N2-fixation, which had marked influence on the growth of groundnut plants and resulted to increase hundred-seed weight of groundnut. The $\mathrm{N} 2$-fixation might have reduced the soil $\mathrm{pH}$ especially in the rhizosphere, thereby increasing the availability of most of the essential macro-and micronutrients in soil for the plant to utilize to improve yield components of groundnut such as hundred seed weight [28]. 


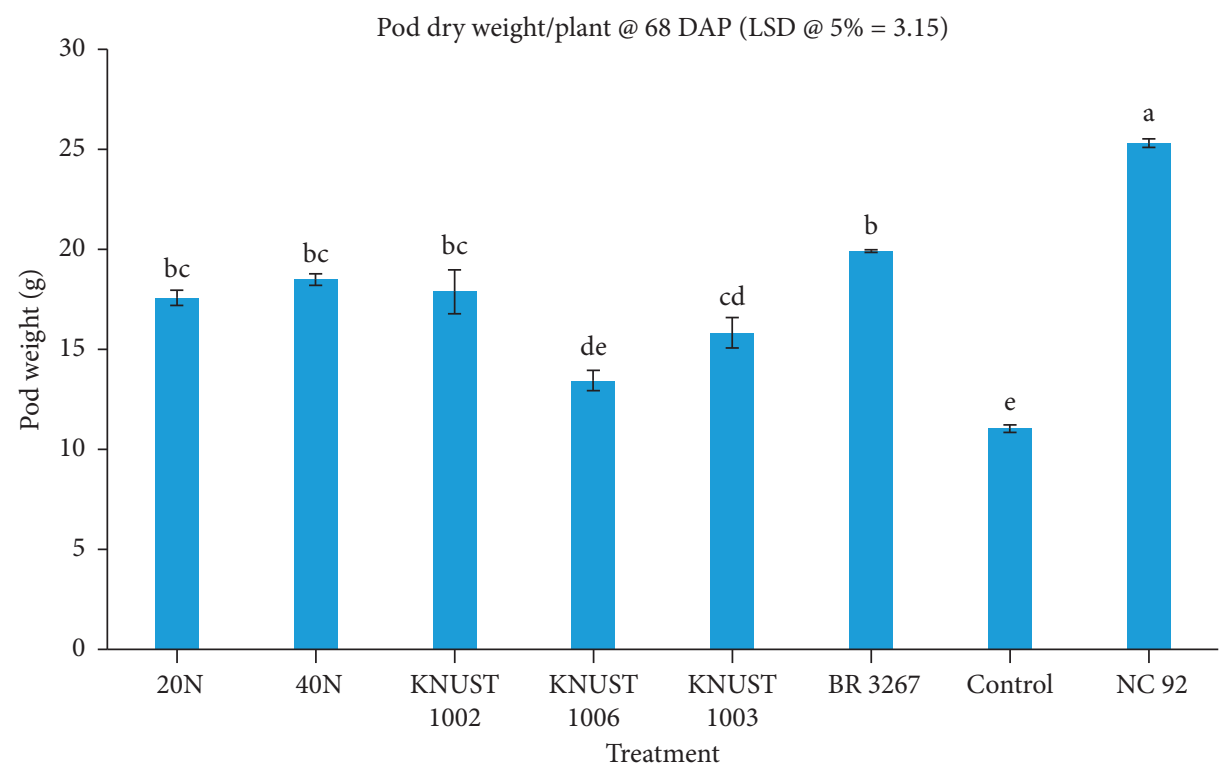

Figure 1: Effects of rhizobial inoculation and $\mathrm{N}$ fertilizer application on pod dry weight per groundnut plant. Bars with different letters denote significance at $P<0.05$. Error bars denote the standard error of means. Means comparison was conducted using least significant difference.

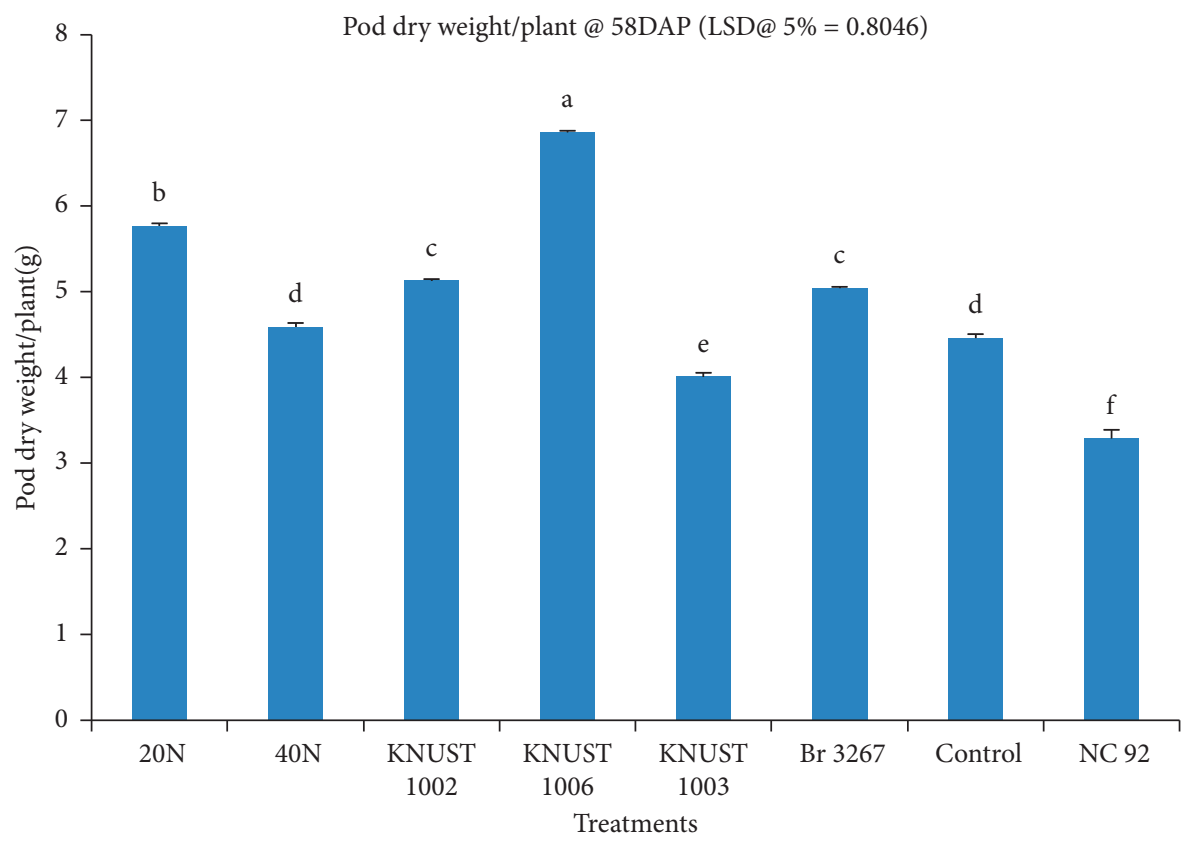

- Series 1

FiguRE 2: Effects of rhizobial inoculation and $\mathrm{N}$ fertilizer application on pod dry weight of cowpea. Bars with different letters denote significance at $P<0.05$. Error bars denote the standard error of means. Means comparison was conducted using least significant difference.

Hundred seed weight in cowpea showed significant difference among the $\mathrm{N}$-applied treatments and inoculant strains, with $\mathrm{Br}-3267$ producing the greatest compared to other rhizobial strains. The KNUST 1003 rhizobial strain performed poorly, which may be as a result of soil conditions, exposure of inoculated seeds to extreme temperatures, or due to the inability of the introduced strain to survive on the seed and also compete successfully with the native strains in the soil. According to [29], the decrease in the population of introduced strains in an inoculant due to death following its introduction into the soil can cause a reduction in the amount required for symbiosis and hence lower seed weight. 


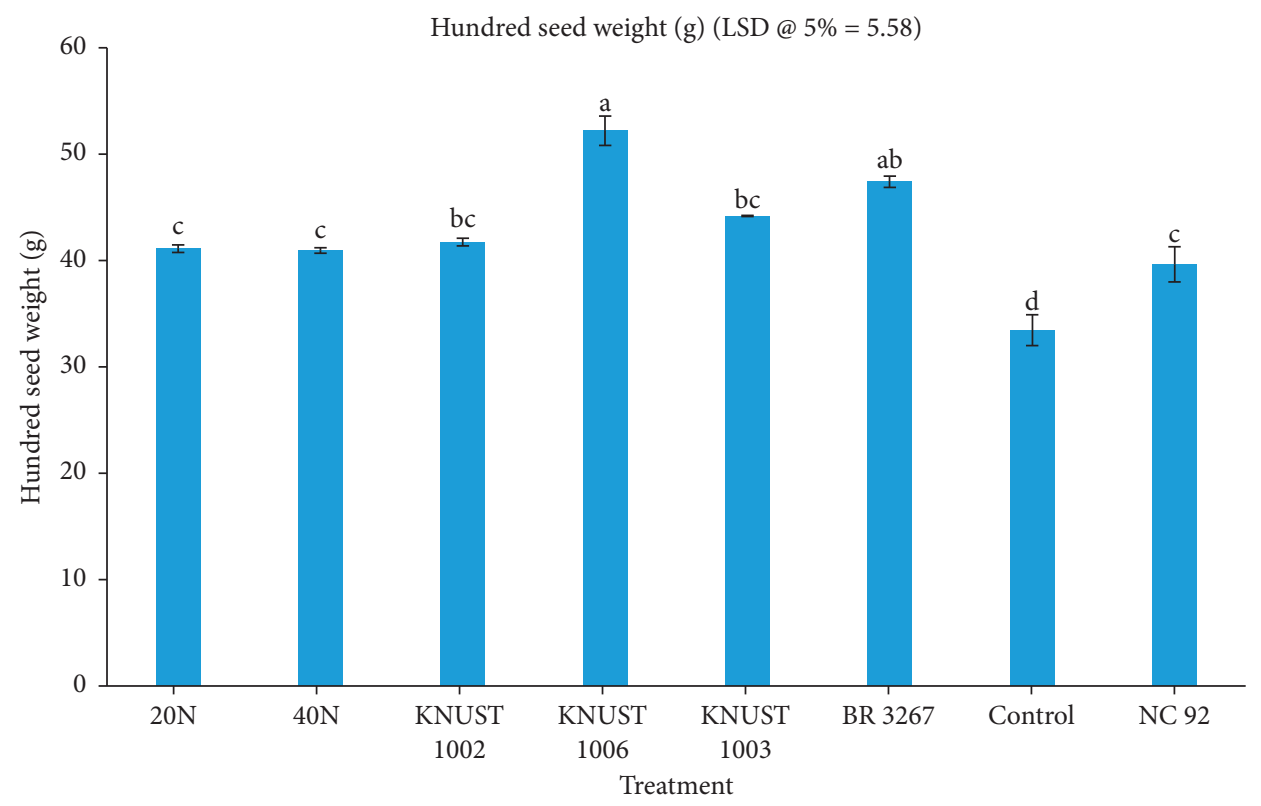

Figure 3: Effects of rhizobial inoculation and $\mathrm{N}$ fertilizer application on hundred seed weight of groundnut. Bars with different letters denote significance at $P<0.05$. Error bars denote the standard error of means. Means comparison was conducted using least significant difference.

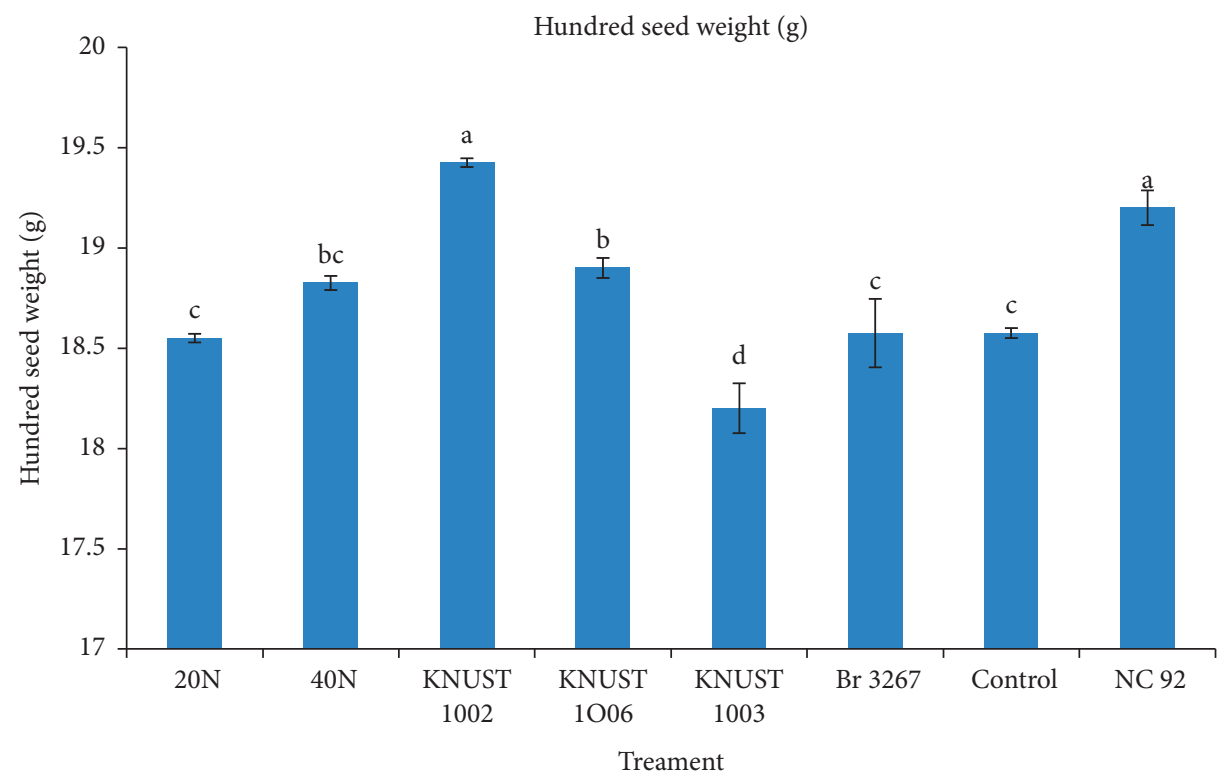

Figure 4: Effects of rhizobial inoculation and $\mathrm{N}$ fertilizer application on hundred seed weigh of cowpea. Bars with different letters denote significance at $P<0.05$. Error bars denote the standard error of means. Means comparison was conducted using least significant difference.

4.5. Grain Yield. The efficiency of the inoculant strain in enhancing nodulation to fix nitrogen in cowpea and groundnut was demonstrated in grain yield relative to the noninoculated plants. The improved nodule weight on cowpea and groundnut may have been due to the fact that the introduced strains were very effective and outcompeted the indigenous Bradyrhizobium spp. The increase in groundnut yield by rhizobial inoculation and $\mathrm{N}$ fertilizer application may be a result of effective nodule tissue accumulation of the rhizobial strains in groundnut, which may have probably helped the plant to fix $\mathrm{N}$ in the soil for the plant to utilize for improved grain yield. This is in line with [30], who suggested that the beneficial role of rhizobia in the $\mathrm{N}$ nutrition through nodulation and effective colonization of the strains at the root zone improves yield. The increased $\mathrm{N}$ fixed probably resulted in the development of more leaves and shoots, which enabled the plant to produce and sink more photosynthates to the lower parts and thus more pods per plant and hence improved yield [26]. Application of phosphorus in the form of TSP to the crops may have 
TABLE 4: Effects of different rhizobial strains and $\mathrm{N}$ fertilizer application on grain yields of cowpea and groundnut grown at Nyankpala in the Guinea Savanna zone of Ghana.

\begin{tabular}{lcc}
\hline \multirow{2}{*}{ Treatment } & \multicolumn{2}{c}{ Grain yield (t/ha) } \\
& Cowpea & Groundnut \\
\hline KNUST 1002 & 1.45 & 0.72 \\
KNUST 1006 & 1.13 & 0.87 \\
KNUST 1003 & 1.19 & 0.81 \\
BR 3267 & 1.41 & 0.98 \\
NC 92 & 1.24 & 1.17 \\
20 N & 1.36 & 0.85 \\
40 N & 1.38 & 0.89 \\
Control & 1.11 & 0.44 \\
LSD (0.05) & 0.4992 & 0.2947 \\
CV (\%) & 26.6 & 23.9 \\
\hline
\end{tabular}

increased the energy level (ATP) of the rhizobia to fix more nitrogen into the soil, which may have contributed to increases in the pod yield. This is in agreement with [22], who reported that a key constituent of ATP in plant is phosphorus, which plays a significant role in transformation of energy in plant. There was no significant difference between the $20 \mathrm{~N}$ and $40 \mathrm{~N}$ treatments even though both of them performed better than the absolute control which generally recorded the least ( 0.44 tons/ha) among the treatments. This is in agreement with [12], who reported that inoculating groundnut with the right strains of rhizobia as biofertilizer and application of $\mathrm{N}$ increased yield of groundnut over the control.

\section{Conclusion}

The study evaluated nodulating strains and its influence on yield components and yield of groundnut and cowpea. Generally, both the fertilizer and the rhizobial strains increased nodule dry weight biomass, pod number, and hundred seed weight resulting in an increased grain yield compared with the control treatments in groundnut. NC 92 strains improved nodulation and total grain yield of groundnut. Nitrogen application at $40 \mathrm{~kg}$. $\mathrm{N}$ increased grain yield; however, it was not significant compared with $20 \mathrm{~kg} \cdot \mathrm{N}$. However, no significance was recorded in cowpea with regard to grain yield. The research therefore recommends farmers to use an efficient rhizobial strain to improve nodulation and yield in cowpea and groundnut production. Mineral N fertilizer can equally improve yield; however, for sustainable intensification of groundnut and cowpea production, biological nitrogen fixation (BNF) is recommended.

\section{Data Availability}

There are no other data used in this study apart from the one included in the manuscript.

\section{Conflicts of Interest}

The authors declare that they have no conflicts of interest.

\section{References}

[1] P. Bogino, F. Nievas, E. Banchio, and W. Giordano, "Increased competitiveness and efficiency of biological nitrogen fixation in peanut via in-furrow inoculation of rhizobia," European Journal of Soil Biology, vol. 47, no. 3, pp. 188-193, 2011.

[2] K. Kumutha and S. Poonguzhali, Biofertilizer Seed Treatment. Seed Quality Enhancement: Principles and Practices356, 2010.

[3] M. M. Alsamowal, M. A. Hadad, and H. Elhassan, "Response of groundnut cultivars to inoculation with indigenous AM Fungi and alien Rhizobial strain under greenhouse conditions," Bioscience Research, vol. 10, no. 2, pp. 65-70, 2013.

[4] A. Jones, "Nodulation competitiveness in the Rhizobiumlegume symbiosis," World Journal of Microbiology \& Biotechnology, vol. 12, no. 2, pp. 157-162, 1996.

[5] F. Pérez-Montaño, C. Alías-Villegas, R. A. Bellogín et al., "Plant growth promotion in cereal and leguminous agricultural important plants: from microorganism capacities to crop production," Microbiological Research, vol. 169, no. 5-6, pp. 325-336, 2014.

[6] G. N. Chemining'wa, J. W. Muthomi, and S. W. M. Theuri, "Effect of rhizobia inoculation and starter-N on nodulation, shoot biomass and yield of grain legumes," Asian Journal of Plant Sciences, vol. 6, no. 7, pp. 1113-1118, 2007.

[7] D. Clavel and J. Gautreau, "L'arachide," in L'amélioration des plantestropicales. Centre de CoopérationInternationale en RechercheAgronomique pour le Développement (CIRAD) et InstitutFrançais de RechercheScientifique pour le Développement en Coopération (ORSTOM), A. Charrier, M. Jacquot, S. Hamon, and D. Nicolas, Eds., Montpellier, Montpellier, France, 1997.

[8] C. K. Tweneboah, Modern Agriculture the Tropics with Special Reference to Ghana Publisher - Cp - Wood, pp. 189-190, Springer, Berlin, Germany, 2000.

[9] M. Hungria and M. A. T. Vargas, "Environmental factors affecting N2 fixation in grain legumes in the tropics, with an emphasis on Brazil," Field Crops Research, vol. 65, no. 2-3, pp. 151-164, 2000.

[10] M. Bekunda, N. Sanginga, and P. L. Woomer, "Restoring soil fertility in sub-Sahara Africa," in Advances in Agronomy, vol. 108, pp. 183-236, Springer, Berlin, Germany, 2010.

[11] J. N. Berchie, H. K. A. Dapaah, A. A. Dankyi et al., "Practices and constraints in Bambara groundnuts production, marketing and consumption in the brong ahafo and upper-east regions of Ghana," Journal of Agronomy, vol. 9, no. 3, pp. 111-118, 2010.

[12] S. Kyei-Boahen, C. E. Savala, D. Chikoye, and R. Abaidoo, "Growth and yield responses of cowpea to inoculation and phosphorus fertilization in different environments," Frontiers in Plant Science, vol. 8, p. 646, 2017.

[13] M. Ashraf, M. Ahmad, and H. M. Bakush, "Efficacy of rhizobial strains for groundnut inoculation under rain fed conditions," Pakistan Journal of Agriculture. Science, vol. 4, pp. 3-4, 2006.

[14] M. E. Abdalla and G. M. Abdel-Fattah, "Influence of the endomycorrhizal fungus Glomusmosseae on the development of peanut pod rot disease in Egypt," Mycorrhiza, vol. 10, no. 1, pp. 29-35, 2000.

[15] C. S. Oaya, A. M. Malgwi, and A. E. Samaila, "Damage potential and loss caused by the groundnut BruchidCaryedonserratus olivier [Coleoptera: bruchidae] on stored groundnut and tamarind in yola. International organization 
of scientific research, India," Journal of Agriculture and Veterinary Science, vol. 1, no. 6, pp. 58-62, 2012.

[16] Y. A. Abayomi, T. V. Ajibade, O. F. Sammuel, and B. F. Saadudeen, "Growth and yield responses of cowpea (Vigna unguiculata (L.) Walp) genotypes to nitrogen fertilizer (NPK) application in the Southern Guinea Savanna zone of Nigeria," Asian Journal of Plant Sciences, vol. 7, no. 2, pp. 170-176, 2008.

[17] P. Bogino, E. Banchio, L. Rinaudi, G. Cerioni, C. Bonfiglio, and W. Giordano, "Peanut (Arachis hypogaea) response to inoculation with Bradyrhizobium sp. in soils of Argentina," Annals of Applied Biology, vol. 148, no. 3, pp. 207-212, 2006.

[18] C. Mathenge, M. Thuita, J. P. Gweyi-Onyango, and M. Cargele, Soybean (Glycine Max) Response to Rhizobia Inoculation and Soil Nitrogen Nairobi, Kenya International Institute of Tropical Agriculture, C/o ICIPE, Department of Agricultural Science and Technology, Kenyatta University, Nairobi, Kenya, 2016.

[19] D. Bhardwaj, M. Ansari, R. Sahoo, and N. Tuteja, "Biofertilizers function as key player in sustainable agriculture by improving soil fertility, plant tolerance and crop productivity," Microbial Cell Factories, vol. 13, no. 1, p. 66, 2014.

[20] X. Zhang, E. A. Davidson, D. L. Mauzerall, T. D. Searchinger, P. Dumas, and Y. Shen, "Managing nitrogen for sustainable development," Nature, vol. 528, no. 7580, p. 51, 2015.

[21] P. B. Ayoola and A. Adeyeye, "Effect of heating on the chemical composition and physico - chemical properties of Arachis hypogea (groundnut) seed flour and oil," Pakistan Journal of Nutrition, vol. 9, no. 8, pp. 751-754, 2010.

[22] L. Nkot, D. Nwaga, N. Albert, H. Fankem, and F. Etoa, "Variation in nodulation and growth of groundnut (Arachishypogaea L.) on oxisols from land use systems of the humid forest zone in southern Cameroon," AfricanJournal of Biotechnology, vol. 10, no. 20, pp. 3996-4004, 2011.

[23] K. Subramaniyan and P. Kalaiselven, "Evaluation of different rhizobial strains for groundnut (ArachishypogaeaL)," Research on Crops, vol. 1, no. 2, pp. 156-158, 2000.

[24] F. Tsigbey, R. Brandenburg, and V. Clottey, "Peanut production methods in northern Ghana and some disease perspectives," in Proceedings of the Sod Based Cropping Systems Conference, North Florida Research and Education Center. Quincy, FL, USA: University of Florida, Quincy, FL, USA, February 2003.

[25] P. K. Ghosh, D. Dayal, K. K. Bandyopadhyay, and M. Mohanty, "Evaluation of straw and polythene mulch for enhance productivity of irrigated summer groundnut," Field Crops Research, vol. 99, no. 2-3, pp. 76-86, 2006.

[26] J. Brockwell, P. J. Bottomley, and J. E. Thies, "Manipulation of rhizobia microflora for improving legume productivity and soil fertility: a critical assessment," Plant and Soil, vol. 174, no. 1-2, pp. 143-180, 1995.

[27] L. Valetti, J. Angelini, T. Taurian et al., "Development and field evaluation of liquid inoculants with native bradyrhizobial strains for peanut production," African Crop Science Journal, vol. 24, no. 1, pp. 1-13, 2016.

[28] J. B. Naab, S. M. Chimphango, and F. D. Dakora, "N 2 fixation in cowpea plants grown in farmers' fields in the Upper West Region of Ghana, measured using $15 \mathrm{~N}$ natural abundance," Symbiosis, vol. 48, no. 1-3, pp. 37-46, 2009.

[29] E. O. Chiamaka, Growth and Yield Response of Cowpea (Vigna Unguiculata [L] Walp) to NPK Fertilizer and Rhizobia Inoculation in the Guinea and Sudan Savanna Zones of Ghana (Doctoral Dissertation), 2015.
[30] X. T. Ju, C. L. Kou, P. Christie, Z. X. Dou, and F. S. Zhang, "Changes in the soil environment from excessive application of fertilizers and manures to two contrasting intensive cropping systems on the North China Plain," Environmental Pollution, vol. 145, no. 2, pp. 497-506, 2007. 